\title{
Anestesi Spinal untuk Seksio Sesarea pada Wanita Hamil dengan Obesitas Morbid
}

\author{
Alfathah Bania Lubis, Tatat Agustian, Djoni Kusumah Pohan, Alexander Siagian \\ Laboratorium Anestesiologi Fakultas Kedokteran Universitas Jenderal Achmad Yani
}

\begin{abstract}
Abstrak
Obesitas adalah keadaan tubuh yang terjadi akibat akumulasi lemak yang abnormal atau berlebih sehingga dapat menimbulkan banyak implikasi klinis dalam tatalaksana anestesi. Wanita hamil dengan berat badan lebih dan obesitas merupakan kondisi yang berisiko tinggi dan terbukti berhubungan dengan peningkatan komplikasi dalam kehamilan. Wanita dengan obesitas sangat penting diberikan edukasi untuk menurunkan berat badan dalam merencanakan kehamilan dan perlu diinformasikan tentang peningkatan risiko termasuk persalinan dengan bedah sesar. Seorang wanita 34 tahun G2P0A1 hamil 41 minggu dengan obesitas morbid dengan tinggi badan $156 \mathrm{~cm}$ dan berat badan $124 \mathrm{~kg}$ dengan nilai indeks massa tubuh (IMT) 50,9 kg/meter2. Pasien menjalani seksio sesarea dengan teknik anestesi spinal, dengan puncture di L3-4 median, menggunakan obat levobupivakain $15 \mathrm{mg}+$ fentanyl 25 mcg. Operasi berlangsung 1 jam 15 menit, perdarahan 350 ml, hemodinamik stabil. Lahir bayi laki-laki, BB 3100 gram, PB $51 \mathrm{~cm}$, APGAR score 8-9-10. Pemilihan teknik anestesi pada wanita hamil dengan obesitas yang akan menjalani seksio sesarea dilakukan dengan jenis anestesi regional yaitu anestesi spinal dengan pertimbangan dapat mengurangi terpaparnya obat-obatan terhadap bayi, mengurangi risiko aspirasi pneumonia dan memungkinkan proses lahirnya bayi dalam keadaan ibu sadar, dapat digunakan untuk mengatasi nyeri pasca operasi, dan juga dapat menghindari risiko bila dilakukan dengan teknik anestesi umum. Simpulan: Wanita hamil dengan berat badan lebih dan obesitas perlu penilaian kondisi dan perencanaan anestesi yang tepat untuk menurunkan risiko seksio sesarea
\end{abstract}

Kata kunci: anestesi spinal, seksio sesarea, obesitas morbid

\section{Spinal Anesthesia for Caesarean Section in Pregnant Woman with Morbid Obese}

\begin{abstract}
Obesity is a state of the body that occurs due to abnormal or excess fat accumulation that can cause many clinical implications in the management of anesthesia. Overweight and obese pregnant women are at high risk and have been shown to be associated with increased complications in pregnancy. Obese women are very important to be educated to lose weight in planning pregnancy and need to be informed about increased risks including delivery by cesarean section. A female, 34 years old G2P0A1, 41 weeks pregnant with morbid obese, $156 \mathrm{~cm}$ tall and weight of $124 \mathrm{~kg}$, with BMI 50,9 kg/meter2. Carried out in spinal anesthesia technique with puncture in L3-4 median, using levobupivacain $15 \mathrm{mg}+$ fentanyl $25 \mathrm{mcg}$. The operation lasted for 1 hour and 15 minutes, with $350 \mathrm{ml}$ bleeding, hemodynamically stable. Born a baby boy, BW 3100 gram, BL $51 \mathrm{~cm}$, APGAR score 8-9-10. Anesthesia technique for pregnant woman with obese who will undergo Caesarean Section is regional anesthesia type called spinal anesthesia with consideration to reduce drug intake for baby, lessen chance of pneumonia aspiration and enable birth process while mother still awake, can be used for overcome post-operation pain, and to avoid risk if done by general anesthesia. Conclusion: overweight and obese pregnant women need proper condition assessment and anesthetic planning to reduce the risk of cesarean section.
\end{abstract}

Key words: spinal anesthesia, caesarean section, morbid obese 


\section{Pendahuluan}

Keadaaan berat badan lebih dan obesitas adalah keadaan pada tubuh yang terjadi akibat akumulasi lemak yang abnormal atau berlebih sehingga dapat mempengaruhi kesehatan. Cara yang mudah dan biasa digunakan dalam dalam menentukan obesitas pada orang dewasa yaitu dengan menghitung indeks massa tubuh (IMT) yang dihitung dengan cara membagi berat badan (dalam satuan kilogram) dengan kuadrat dari tinggi badan (dalam satuan meter) dan hasilnya dibulatkan menjadi satu desimal. ${ }^{1}$ Kriteria berat badan lebih didapatkan apabila hasil perhitungan IMT $25-29,9 \mathrm{~kg} / \mathrm{m}^{2}$ dan kriteria obesitas didapatkan lebih dari atau sama dengan $30 \mathrm{~kg} / \mathrm{m}^{2}$.

Namun demikian Organisasi Kesehatan Dunia (WHO) menemukan massa lemak yang lebih tinggi pada populasi di Asia bila dibandingkan dengan populasi lain dengan IMT yang sama. Maka diperlukan intervensi pada IMT yang lebih rendah untuk populasi Asia termasuk Indonesia. WHO menentukan kriteria lebih dari atau sama dengan $23 \mathrm{~kg} / \mathrm{m}^{2}$ untuk berat badan lebih dan lebih dari atau sama dengan $25 \mathrm{~kg} / \mathrm{m} 2$ untuk obesitas pada populasi Asia. ${ }^{2}$ Prevalensi berat badan lebih dan obesitas di dunia mencapai 2,1 miliar pada tahun 2013 dan terus meningkat dari 857 juta pada tahun 1980 . Berdasarkan data yang dihimpun oleh CDC, prevalensi obesitas pada orang dewasa tahun 1999-2000yaitu 30,5\% dan sangatmeningkat pada tahun 2015-2016 yang mencapai 39,6\% dengan angka tertinggi pada kelompok usia 40-59 tahun yaitu sebesar $42,8 \%$ pada wanita maupun pria.

Berdasarkan data dari Riset Kesehatan dasar (RISKESDAS) tahun 2013, prevalensi penduduk dewasa di Indonesia yang mengalami berat badan lebih dan obesitas sebesar 28,9\%, meningkat dari tahun 2007 sebesar 19,8\%, dan 23,9\% pada tahun 2010. Data di Indonesia menunjukkan wanita lebih banyak mengalami berat badan lebih dan obesitas dibanding laki-laki, dengan prevalensi obesitas pada wanita dewasa sebesar $32,9 \%$ pada tahun 2013 dibandingkan 19,7\% pada laki-laki dewasa di tahun yang sama.
Prevalensi obesitas pada wanita tahun 2013 ini sangat meningkat dibandingkan tahun 2007 sebesar 13,9\% dan tahun 2010 sebesar $15,5 \%{ }^{3}$ Berat badan lebih dan obesitas terutama pada wanita usia subur merupakan keadaan sebelum hamil yang paling sering ditemukan. Pada penelitian di Montpillier Prancis tahun 19931994 ditemukan sekitar 29,6\% wanita hamil mempunyai IMT $>25 \mathrm{~kg} / \mathrm{m}^{2}$ sebelum hamil. ${ }^{4}$ Namun demikian prevalensi berat badan lebih dan obesitas pada kehamilan sulit ditentukan karena sampai saat ini belum ada indikator yang disepakati untuk menentukan berat badan lebih dan obesitas pada kehamilan. ${ }^{5}$

Metode lain yang dapat digunakan untuk menentukan obesitas dalam kehamilan adalah menentukan lemak tubuh dengan menghitung ketebalan lipatan kulit dan lingkar lengan atas. ${ }^{6}$ Wanita hamil dengan berat badan lebih dan obesitas merupakan kondisi yang beresiko tinggi dan terbukti berhubungan dengan peningkatan komplikasi dalam kehamilan seperti abortus spontan, kelainan kongenital janin, pertumbuhan janin yang terhambat, gangguan toleransi glukosa dan diabetes gestasional, peningkatan resiko infeksi, tromboemboli, hipertensi dalam kehamilan, bahkan kematian ibu dan janin. ${ }^{7-8}$

Pada periode antenatal, berat badan lebih dan obesitas berhubungan dengan terjadinya hipertensi dalam kehamilan, dan terjadinya komplikasi berat hipertensi seperti sindrom HELLP (hemolysis, elevated liver enzyme, low platelet). ${ }^{9}$ Pada periode intrapartum berat badan lebih dan obesitas akan berdampak pada proses persalinan. Sebuah analisis menemukan bahwa berat badan lebih dan obesitas akan meningkatkan risiko seksio sesarea. ${ }^{10}$ Kegagalan percobaan persalinan pada pasien obesitas morbid juga meningkatkan risiko morbiditas maternal sebanyak 6 kali dibandingkan dengan kelompok yang berhasil. ${ }^{11}$ Pada wanita dengan berat badan lebih dan obesitas sangat penting diberikan edukasi untuk menurunkan berat badan dalam merencanakan kehamilan. Dan perlu diinformasikan tentang peningkatan risiko termasuk persalinan dengan bedah sesar. ${ }^{12}$ 


\section{Kasus}

\section{Riwayat penyakit}

Seorang wanita 34 tahun, merasa hamil 41 minggu, anak ke 2, masih merasakan gerakan janin. Perut dirasakan mules yang hilang timbul, keluar cairan dari jalan lahir (-), lendir darah (-), pusing (-), pandangan kabur (-), sesak nafas (-), nyeri dada (-), sesak nafas (-), demam(-).

\section{Pemeriksaan Fisik}

Pemeriksaan fisik didapatkan tekanan darah 110/70 $\mathrm{mmHg}$, nadi $98 \mathrm{kali} / \mathrm{menit}$, frekwensi nafas $20 \mathrm{kali} / \mathrm{menit}$. Suhu $36,5^{\circ} \mathrm{C}, \mathrm{SpO}_{2} 98 \%$. Tinggi badan $156 \mathrm{~cm}$ dan berat badan $124 \mathrm{~kg}$ dengan nilai IMT 50,9 kg/meter2.

\section{Pengelolaan Anestesi}

Pasien didiagnosa dengan G2P0A1 hamil 41 minggu dengan obesitas morbid. Dilakukan teknik anestesi regional yaitu anestesi spinal dengan puncture di L3-4 median, menggunakan obat levobupivakain $15 \mathrm{mg}+$ fentanyl $25 \mathrm{mcg}$. Operasi berlangsung 1 jam 15 menit, perdarahan $350 \mathrm{ml}$, hemodinamik stabil. Lahir bayi lakilaki, BB 3100 gram, PB $51 \mathrm{~cm}$, APGAR score 8-9-10. Post operasi kesadaran composmentis, tekanan darah 120/80 $\mathrm{mmHg}$, nadi $84 \mathrm{kali} /$ menit,

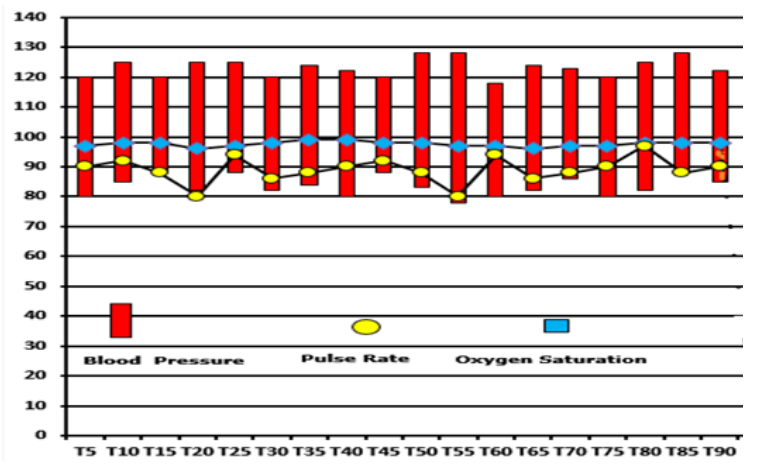

Grafik 1. Pengamatan Tanda Vital selama Operasi

Pemeriksaan Penunjang

Tabel 1. Pemeriksaan Laboratorium

\begin{tabular}{|c|c|c|c|c|}
\hline Pemeriksaan & Hasil & Satuan & Nilai rujukan & Keterangan \\
\hline \multicolumn{5}{|l|}{ Hematologi } \\
\hline Hemoglobin & 12,3 & $\mathrm{~g} / \mathrm{dl}$ & $11,0-16,0$ & \\
\hline Eritrosit & 4,2 & $10^{\wedge} 6 / \mathrm{uL}$ & $4,0-5,5$ & \\
\hline Lekosit & 22,3 & $10^{\wedge} 3 / \mathrm{uL}$ & $4,0-10,0$ & \\
\hline Hematokrit & 35,3 & $\%$ & $36,0-48,0$ & \\
\hline Trombosit & 346 & $10^{\wedge} 3 / \mathrm{uL}$ & $150-450$ & \\
\hline \multicolumn{5}{|l|}{$\mathrm{MCV}, \mathrm{MCH}, \mathrm{MCHC}$} \\
\hline $\mathrm{MCV}$ & 83,8 & $\mathrm{fL}$ & $75,0-100,0$ & \\
\hline $\mathrm{MCH}$ & 29,2 & $\mathrm{Pq}$ & $25,0-32,0$ & \\
\hline $\mathrm{MCHC}$ & 34,8 & $\mathrm{~g} / \mathrm{dL}$ & $32,0-36,0$ & \\
\hline RDW & 13,8 & $\%$ & $10,0-16,0$ & \\
\hline \multicolumn{5}{|l|}{ Hitung Jenis } \\
\hline Basofil & 0,3 & $\%$ & $0,0-1,0$ & \\
\hline Eosinofil & 0,9 & $\%$ & $1,0-4,0$ & \\
\hline Neutrofil & 83,9 & $\%$ & $50,0-80,0$ & \\
\hline Limfosit & 8,5 & $\%$ & $25,0-50,0$ & \\
\hline Monosit & 6,4 & $\%$ & $4,0-8,0$ & \\
\hline NLR & 9,87 & & & Cut off 3,13 \\
\hline \multicolumn{5}{|l|}{ SERO-IMUNOLOGI } \\
\hline $\begin{array}{l}\text { SARS-Cov-2 antibody } \\
\text { (IgG-IgM) }\end{array}$ & & & & Non reaktif \\
\hline
\end{tabular}


frekwensi nafas $20 \mathrm{kali} /$ menit. $\mathrm{SpO}_{2} 99 \%$ dengan nasal kanul 3 liter/ menit. Analgetik post op dexketoprofen + fentanyl.

\section{Pengamatan Pascaoperasi}

Pascaoperasi kesadaran pasien composmentis, tekanan darah 120/80 mmHg, Nadi 84 kali/menit, frekwensi nafas $20 \mathrm{kali} /$ menit. $\mathrm{SpO}_{2} 99 \%$ dengan nasal kanul 3 liter/menit. Analgetik pascaoperasi dexketoprofen + fentanyl. Kondisi hemodinamik stabil pascaoperasi seperti terlihat pada Gambar 2. Hasi pengamatan pascaoperasi pada jam ke 1 sampai dengan jam ke 24 tekana darah sekitar 120128/79-88 mmHg, denyut jantung sekitar 70-86 $\mathrm{x} /$ menit dan saturasi oksigen sekitar 96-100\%.

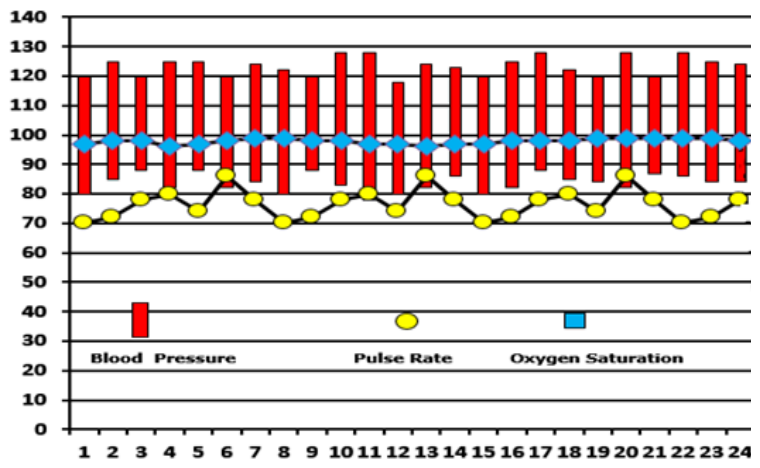
Gambar 2: Pengamatan Tanda Vital 24 Jam Pasca Operasi

\section{Pembahasan}

Pada wanita hamil dengan IMT sebelum hamil $>30 \mathrm{~kg} / \mathrm{m}^{2}$, rencana persalinan perlu dikonsultasikan dan diputuskan dengan spesialis obstetri dan ginekologi. Pasien diberitahu tentang risiko terjadinya kelainan-kelainan yang mungkin terjadi. Juga konsultasi dengan spesialis anestesi karena pada pasien obesitas tindakan anestesi menjadi lebih sulit karena bagian tubuh penanda lokasi anestesi sulit dicari. ${ }^{5,13,14}$ Pemilihan teknik anestesi untuk seksio sesarea dipengaruhi beberapa faktor seperti indikasi operasi, kepentingannya, pilihan pasien dan ketrampilan dari dokter anestesi. Proses melahirkan secara seksio sesarea diberbagai negara insidensinya berbeda-beda. Diberbagai rumah sakit Amerika didapatkan insidensi sekitar 15-35\%, dan banyak tindakan seksio sesarea dilakukan dengan jenis anestesi regional yaitu spinal anestesi. Hal ini
Tabel 2. Klasifikasi IMT Berdasarkan $\mathrm{WHO}^{2}$

\begin{tabular}{lcl}
\hline Status Nutrisi & Kriteria WHO & $\begin{array}{l}\text { Kriteria WHO } \\
\text { untuk Asia }\end{array}$ \\
\hline $\begin{array}{l}\text { Berat badan } \\
\text { kurang }\end{array}$ & $<18,5$ & $<18,5$ \\
Normal & $18,5-24,9$ & $18,5-22,9$ \\
Berat badan & $25,0-29,9$ & $23,0-24,9$ \\
lebih & & \\
Praobesitas & - & $25,0-29,9$ \\
Obesitas I & $30,0-34,9$ & $30,0-34,9$ \\
Obesitas II & $35,0-39,9$ & $35,0-39,9$ \\
Obesitas III & $\geq 40,0$ & $\geq 40,0$ \\
\hline
\end{tabular}

Keterangan: IMT: indeks massa tubuh

dikarenakan bila dengan teknik anestesi umum sangat erat berhubungan dengan resiko yang sangat besar dan berhubungan dengan morbiditas dan mortalitas ibu yang tinggi. ${ }^{15}$ Keuntungan dari anestesi regional yaitu mengurangi potensi terpaparnya obat-obatan terhadap bayi, mengurangi resiko aspirasi pneumonia, ibu dalam keadaan bangun saat melahirkan dan dapat digunakan untuk mengatasi nyeri post operasi. ${ }^{15,16}$ Teknik anestesi spinal dan anestesi epidural, baik secara masing-masing atau kombinasi adalah teknik yang banyak digunakan untuk mengatasi nyeri saat melahirkan termasuk seksio sesarea dengan menghasilkan analgesia yang sempurna. ${ }^{15-17}$ Teknik regional pada seksio sesarea pada wanita hamil dengan obesitas mobid mempunyai tingkat kesulitan tersendiri yang disebabkan oleh tebalnya jaringan lemak sehingga sulit untuk melakukan palpasi dari prosesus spinosus dan ruang intervertebralis. Hal ini dapat dibantu mengatasinya dengan menarik garis penunjuk dari prosesus spinosus ruas tulang servikal ke 7 ke lekukan pada bagian pantat dan lekukan bagian belakang tubuh pasien, atau dapat dibantu dengan menggunakan alat ultrasonografi (USG). Untuk lebih memudahkan lagi para praktisi sering memposisikan pasien obesitas dalam posisi duduk, yaitu untuk memudahkan melihat garis tengah ruas tulang belakang. ${ }^{15-17}$

\section{Simpulan}

Pasien wanita hamil dengan obesitas yang akan menjalani seksio sesarea memiliki banyak 
implikasi klinis yang harus dipertimbangkan dalam teknik anestesi. Pemahaman patofisiologi akan membantu memberikan teknik anestesi yang lebih baik. Pemilihan teknik anestesi pada wanita hamil dengan obesitas yang akan menjalani seksio sesarea dilakukan dengan jenis anestesi regional yaitu anestesi spinal dengan pertimbangan dapat mengurangi terpaparnya obat-obatan terhadap bayi, mengurangi resiko aspirasi pneumonia dan memungkinkan proses lahirnya bayi dalam keadaan ibu sadar, dapat digunakan untuk mengatasi nyeri post operasi, dan juga dapat menghindari resiko bila dilakukan dengan teknik anestesi umum.

\section{Daftar Pustaka}

1. Hales CM, Carroll MD, Fryar CD, Ogden CL. Prevalence of obesity among adults and youth; United States, 2015-2016. NCHS Data Brief, 2017; 288 (288): 1-8.

2. Barba C, Cavalli-Sforza T, Cutter J, Darnton-Hill I, Deurenberg P, Deurrenberg $\mathrm{YM}$, et al. Appropiate body-mass indexfor Asian populations and its implications for policy and intervention strategies. Lancet, 2004;363(9403):157-63.

3. Badan Penelitian dan Pengembangan Kesehatan. Riset Kesehatan dasar (RIKKESDAS) 2013. LapNas 2013;1-384.

4. Galtier-Dereure F, Boegner C, Bringer J, Obesity and pregnancy: complications and cost Am J clin Nutr 2000; 1242S-8S.

5. Davies GA, Maxwell C, McLeod L, Gagnon $\mathrm{R}$, Basso M, Bos H, etal. Obesity in pregnancy. J Obs Gynaecol Can 2010;32(2):165-73.

6. Gunatilake RP, Perlow JH. Obesity and pregnancy: clinical management of the obese gravida. Am J Obstet Gynecol. 2011;204(2):106-19.

7. Agnihorti S. Obesity: time to re-examine care for pregnant women. $\mathrm{Br} \mathrm{J}$ Obes 2016;1(3):94-8.
8. Weiss JL, Malone FD, Emig D, Ball RH, Nyberg DA, Comstock CH, et al. Obesity, obstetric complications and caesarean delivery rate-population-basedscreening study. Am J Obstet Gynecol.2004;190(4):1091-7.

9. Robinson HE, O'Connel CM, Joseph KS, McLeod NL. Maternal outcomes in pregnancies complicated by obesity. Obstet Gynecol, 2005;106(6):1357-64.

10. Chu SY, Kim SY, Schmid CH, Dietz PM, Callaghan WM, Lan J, et al. Maternal obesity and risk of caesarean delivery: A metaanalysis. Obes Rev, 2007;8(5):385-94.

11. Hibbard JU, Gilbert S, Landon MB, Hauth JC, Leveno KJ, Spong CY, et al. Trial of labor or repeat caesarean delivery in women with morbid obesity and previous caesarean delivery. Obs Gynecol. 2006;108(1):125-33.

12. Yu CKH, Teoh TG, Robinson S, Spellacy W, Sewell M, et al. CMACE/RCOG Joint Guideline: Management of Women with Obesity in Pregnancy. BJOG 2010; 113(4):CD007122.

13. ACOG. Obesity in Pregnancy. Obstet Gynecol 2015;126(6):e112-e.

14. The Royal Australian and New Zealand College of Obstetricians and Gynecologists. Management of obesity in pregnancy, RANZCOG College Statement, 2013.

15. Butterworth JF, Mackey D,Wasnick JD. Clinical Anesthesiology: Obstetric Anesthesia. 2013; 5:843-60.

16. Ende H, Kodak B Anesthesia for the morbidly obese pregnant patient. In: Gunaydin B, Ismail S. Obstetric Anesthesia for Co-morbid Condition. Springer; 2018;4:53-65.

17. Hadzic A. Textbook of Regional Anesthesia and Acute Pain Management. 2017;2: 77395. 